\title{
Study on Quality Evaluation System Construction of College Education Online Service
}

\author{
Xiaodun Deng ${ }^{1, \text { a }}$ \\ ${ }^{1}$ Xi'an International University, Xi'an, Shaanxi, 710077 \\ a email
}

Keywords: Universities, Online Education, Quality of Service, Evaluation System

\begin{abstract}
Modern science extremely rapid development of information technology, the use of scientific information technology for online education is already a relatively unusual thing in higher education, many high-quality curriculum resources can be shared and applied by means of online education. And every colleges or universities online education has its own curriculum quality evaluation criteria, in order to share high-quality curriculum resources, and sustainable development education online courses, you need to build a sound quality of educational services online university evaluation system. And for the College online educational service quality system, this paper related discussion and study.
\end{abstract}

\section{Introduction}

In the modernization of education in the form of higher education pursue online education to get the teachers and students of affirmation and recognition. In general, online education universities mainly in elective courses [1]. Students can choose courses based on their interests and preferences, and are free to choose class time, in time and space to enjoy full freedom. And the quality of online courses educational services, since there are different standards for online course evaluation of education are different. Therefore, this article of university education online course quality service specific elaboration.

\section{The Quality of Education and Universities Online Services}

Online education actually refers to the implementation of the use of network video teaching model, which is currently a very popular way to class, diverse as its platform open network education platform, Netease open class, MOOC like. The so-called Colleges Online education also have the same characteristics, is that college students through online education platform independent learning the content of a discipline, and complete the required teaching activities, and finally obtain the total course credits [2].

According to the concepts of online education Universities, colleges and universities online education can be seen very own characteristics. Colleges Online education has the biggest feature is to provide personalized service, the students in a certain range can choose curricula, in accordance with the wishes of the individual student. In addition, students in the process of acceptance of online education services, you can play video as they wish or pause the video, if the student does not feel completely absorbed in online education teaching content can also be re-read it. In addition, the designers of online education homework for the same video teaching content arrangements are different. Therefore, the university has a higher education online personalization features. Of course, online education colleges and universities also have other features, such as the size of the High Line online education is relatively large, with a relatively integrity and so on.

Universities and quality of educational services is online courses college students in the process of acceptance of online education, online education meets the needs of students, whether the effect of online education. College students and teachers to quality education of university courses online service to make a relatively objective and fair assessment, we need to build the quality of education in University online service evaluation system [3]. On this basis, to promote better development of online education colleges and universities, but also to enhance the ability of independent learning. 


\section{The Problems in Universities Online Educational Service Quality}

Colleges Online education is mainly conducting educational activities in the form of a network, in time and space students have gained the largest free online education reflects the great advantage. However, at the same time the quality of colleges and universities online education is also facing great challenges. Students to online learning, education also means that there is in the network environment, students are more likely to be affected by other factors [4]. Second, some students choose online education network aim is to take advantage of online education from the teachers' control. Students can play video, it can also be free to do other things. This makes online education purpose and effect of teaching dropped sharply. Online learning on student's point of view, the quality of online education is facing greater challenges.

In addition, the challenges facing colleges and universities online education is mainly reflected in the production level of online education. Quality of Higher Education courses online service requires the designer behind the support, including online video educational process of making the team determined the course curriculum to provide funding, curriculum process monitoring and so on, no matter which side will be a problem in making online education affect the quality of online education courses. Of course, online education is not only a school will be produced, and in contrasting case, the quality of online education services will come out, but there are also competitive online education problems, so online Educational Courses faced in this regard a greater degree of challenge.

\section{Evaluation System of Online Universities Education Service Quality}

According to College online educational service quality evaluation system of its existence can be seen in the development process as well as the advantages of the problems, the designer thus relevant online education you can continue to improve, so as to continuously optimize the school education system, improve the university online quality of education. The construction of institutions of higher learning as the main course, students as the main participants need to make some contribution to this end.

About Online College Education Service Quality Evaluation System can be divided into two categories according to different evaluation body, the Ministry of Education Higher Education Evaluation Center one is established in 2004 on the evaluation and assessment of online courses, which contains a teaching content, curriculum resources, teaching methods and evaluation of student learning [5]. The other is the quality of students and teachers online education services were evaluated. In this type of evaluation, and many other segments of the evaluation project. For example, standing on the perspective of students, evaluation Details online education in the evaluation of teaching content, teaching methods, there is the evaluation of learning resources and services provided by online education, online education has homework evaluation and so on. Standing teacher's perspective, there is the evaluation of online educational facilities and so on. Quality of Higher Education courses online service based on the evaluation results of these two categories, and then make the appropriate adjustments, the quality of service in the school of education will certainly rise.

\section{Construction of College Online Education Service Quality Evaluation System}

In order to ensure and improve the quality of colleges and universities online education services, we need to build more comprehensive and complete online education service quality evaluation system. The system can also be constructed from the amount of aspects: First, from colleges and universities online education relevant authorities to start, the relevant authorities on the quality of service online education curriculum evaluation and assessment; the second is from the main recipients of University online education and participation who start online education evaluation. These two major aspects, the College online educational service quality evaluation system can significantly help to improve the quality of online education services, and promote long-term development of 
online education [6]. The following is a specific elaboration on these two areas.

Online education management body of institutions of higher learning and universities is related to the education sector, build online education evaluation system naturally requires the participation of university management body. Due to the different responsibilities of University online curriculum manager for online education should also be produced using different evaluation rules, and then for the majority of students to provide a better quality of education services.

Online education produced contains many managers, this paper mainly to design university administrators of online education, for example, to build a concrete analysis of architecture and related procedures Colleges online educational service quality evaluation system.

First, college education online designer on duty to ensure the quality of all courses online education platform. For example, video production and design of online education should be clear clear, to ensure that students in the education process to enjoy a more comfortable viewing environment. As another example, a video player online education can be adapted to a large number of students to watch the same time, ensure smooth online education. Furthermore, in order to provide students with a better service, design manager online education should be a complete set of online educational system, which contains video content online education, online learning materials, online customer service, and so on. Of course, online education network on web design there are many other content, this paper will not enumerate. Therefore, the quality of education to build online services can determine the corresponding responsibilities in accordance with the evaluation criteria of online education design manager.

It is also worth noting that the use of online education for the students to receive the convenience of playing video but do not watch the phenomenon of false pretenses, the designer should design management related methods of supervision, try to ensure high quality line of online education at this level to provide more advanced services. Evaluation System content can also be change.

The main participants in online education is the College students and teachers, so students and teachers question the quality of education for the online services have the final say, the main assessment of university Online education is mainly students and teachers. Design of online education university administrators must first realize the importance of building online education evaluation system in web design when you need to integrate into relevant evaluation system design. Page online educational evaluation system designed primarily to teaching content and teaching activities related to the object, so that students evaluated. To try to maintain a fair and objective manner when conducting student evaluation, content evaluation, including teaching methods, teaching methods, teaching content, teaching activities, after-school jobs, etc., can be evaluated. Student Assessment generally use questionnaires, relying on online education platform, reflecting the quality of the course the situation through qualitative and quantitative methods. The main way to evaluate the student may be given the option of choice, it can be to express their opinions or suggestions.

Evaluation of online education as far as possible on the whole every aspect of online education evaluation, evaluation of the content to be scientific and rational design, and students must adhere to the principle of relatively objective evaluation. In addition, since the entire college education online course evaluation system involving extensive and complex content, it should be noted that in the implementation of the evaluation time of the evaluation.

All in all, the university online education service quality appraisal system takes time and energy, the need to constantly update and improve, this is not a simple matter.

\section{Conclusion}

Online College Education in China has grown to a certain extent, and in order to provide better service and to allow students to enjoy more high-quality courses to meet the needs of social development, the quality of colleges and universities online education services need to continuously upgrade. Therefore, building a relatively complete university online service quality evaluation system is a very important task. Through modern science and information technology, to promote the development of university education. Education information technology to promote the process 
of modernization of education, university curriculum and teaching reforms. Online education gains of the revolution into the modernization of education outcomes, and promote the integration of information technology and curriculum, in order to cultivate socialist construction require innovative talents for our country to contribute.

\section{Acknowledgements}

Shaanxi Provincial Institute of Higher Education in 2015--2016 annual high-level research projects in Private Universities, Service Quality in Higher Distance Education Evaluation System Construction. 15GJ044.

Xi'an 2016 Annual Social Science Planning Fund projects. Online College Education Service Quality Evaluation System Construction. 16IN13.

\section{References}

[1] Linda - Harasim, Xiao Junhong. collaborative learning theory and practice - the quality of online education is the fundamental guarantee [J]. China Distance Education, 2015,08: 5-16 + 79.

[2] Miao Wenlong. university online courses Construction of Quality Assurance System [D]. East China Normal University, 2015.

[3] Yuan Li, Stephen • Powell, Bill • Oliver, Ma Hongliang. after a sequence of ideas MOOC era: Sustainable Development of University Online Education [J]. Education Research, 2014,03: 44-52.

[4]. Wu Xiaoqiong, Xing Yanfang. online education development path of [J]. Xinzhou Teachers University, 2015,01: 87-90.

[5] Janet • Gregory, Du Xian. online education: Challenges and Opportunities [J]. Beijing Radio and Television University, 2014,06: 24-28.

[6] $\mathrm{Xu}$ Suyan. the development of teaching reform online education courses at colleges and universities [J]. Education Exploration, 2014,04: 97-102. 